\title{
The Contribution of Management Commentary Index (Ma.Co.I) in Annual Banking Reports (ABR) and the Chronicle of the Great Greek Crisis
}

\author{
Alexandros Garefalakis, Augustinos Dimitras \\ Department of Social Science, Hellenic Open University, Patra, Greece \\ Email: agarefalakis@staff.teicrete.gr,dimitras@eap.gr
}

How to cite this paper: Garefalakis, A. and Dimitras, A. (2016) The Contribution of Management Commentary Index (Ma.Co.I) in Annual Banking Reports (ABR) and the Chronicle of the Great Greek Crisis. Theoretica Economics Letters, 6, 1060-1087. http://dx.doi.org/10.4236/tel.2016.65103

Received: August 3, 2016

Accepted: September 20, 2016

Published: September 23, 2016

Copyright $\odot 2016$ by authors and Scientific Research Publishing Inc. This work is licensed under the Creative Commons Attribution International License (CC BY 4.0).

http://creativecommons.org/licenses/by/4.0/

\begin{abstract}
The research explores the extent to which the implementation of International Financial Reporting Standards (IFRS) in the Greek banking sector has affected its financial and narrative reporting between the periods prior (2002-2004) and after (2005-2010) the implementation of the IFRS. In particular, we examine the relation between Price per Share (P), Earnings per Share (EPS) and the Book Value (BV) per share using data from listed banks of Athens Stock Exchange (ASE). Further, the change of the narrative reporting quality of the Greek banking sector is studied along with the key financial indicators trends between the two above periods. Moreover, we investigate the disclosure quality of narrative information of annual reports for the period after the Greek financial crisis (i.e. from 2008 to 2010). Finally, we assess the relation between the key financial indicators and Management Commentary (MC). The findings indicate a positive relationship between $\mathrm{P}, \mathrm{BV}$ and EPS after the first period of IFRS adoption (i.e. from 2005 to 2007). In addition, we report that MC has been considerably improved in the same period, while a positive impact in the key financial Indicators has been observed. Furthermore, empirical evidence specifies that Debt tends to be the most important indicator of Management Commentary. Finally, in the beginning of Greek crisis period the disclosure quality of narrative portion of annual reports are lower except. An important innovative characteristic of the above results is that the Management Commentary Index (Ma.Co.I) is able to measure the actual quality of Annual Banking Reports (ABR) and provide a reliable and unique tool for the investors.
\end{abstract}

\section{Keywords}

IFRS, Annual Banking Reporting Quality, Management Commentary, Ma.Co.I 


\section{Introduction}

According to the European Community Regulation No. 1606/2002, all the European Union listed companies are required to prepare their consolidated financial statements in accordance to International Financial Reporting Standards (IFRS) as from 1 January 2005. The main faculty of the IFRS implementation in the EU is its ability to enhance comparability and to improve the quality of the firms' financial statements. As the International Accounting Standards Board (IASB), [1] points out, the companies' annual reports are separated in two main constituents: a) the narrative information where the management team gives qualitative information while comments and analyses key issues of an enterprise's vision, mission, financial prospects and strategy and b) the financial results where annually quantitative financial information are presented in the form of balance sheets, cash flow statements, ratios and financial ratios. The importance of the annual reports narrative portion has been recognized by practitioners and researchers where the advances in the improvement of the amount and the quality of information provided to investors, lenders, among others, is judged as significant. This narrative portion in the financial statements is referred to as "Management Discussion and Analysis-MD\&A" in the US and "Operating and Financial Review_OFR" or "Business Review" in the UK. However, in most European countries, it is called "Management Commentary (MC)". The [1] defines the notion of $\mathrm{MC}$ as "the information that accompanies financial statements as being a part of an entity's financial reporting. It explains the main developments and issues underlying the progress, performance, and position of the entity's business during the period covered by the financial statements. Furthermore, it presents and analyses the main trends and factors that are likely to affect the entity's future development, performance and position".

The investigated parts of this research are four. The first part examines the impact of the IFRS adoption in the Greek banking sector by addressing a hypothesis on how the value relevance of earnings and book value has changed between the periods prior (2002-2004) and after (2005-2010) the implementation of the IFRS. To answer this question, the Ohlson model $(\mathrm{OM})$ is utilised, presenting a linear relationship between Price per share (P), EPS and Book Value (BV). We used an evaluation framework suggested by [2] which expresses a stock's value as a function of Earnings per Share (EPS) and the Book Value (BV) per share; in particular, we applied regression analysis on stratification data. Our results are supported by the findings of [3] and [4], who concluded that the assumption of the relevance of accounting values could not be rejected. The second part compares the quality of narrative information disclosed in the Annual Banking Reports (ABR). The purpose of the latter investigates how and whether the quality of narrative financial reports information has changed between the pre-IFRS (2000-2004) and first post-IFRS (2005-2007) periods. The Management Commentary Framework (MCF) analysis was conducted using an Index of 70 indicators (questions) divided in 5 categories (the Management Commentary Index-Ma.Co.I), which proposed by the [5].

The third part reports the quality of narrative information of annual banking reports 
using the Ma.Co.I index; we consider data for the period after the Greek financial crisis (2008-2010). Key Performance Indicators (KPIs) are used to enhance understanding of the quality of narrative information disclosure in a very important transitional period [6]. Finally, Spearman's rank correlation coefficient is considered to assess the relationship between the key financial indicators and the quality of the Ma.Co.I.

Our reported results indicate that the Ohlson model has been utilized proposing a linear relationship between P, BV and EPS measured on a per share basis; we find that the P has been positively related to BV and EPS after the implementation of the IFRS principles (this is in contrast with the results for the period before the IFRS). Moreover, the results show that MC has been considerably improved in the same period, while a positive impact in the key financial indicators has been observed. Furthermore, we find that Debt tends to be the most important indicator of MC, while in the beginning of Greek crisis period the disclosure quality of narrative portion of annual reports are lower. Finally, the Ma.Co.I which constructed by Alexandros Garefalakis and published 3 years ago to [6] study shows practically (in this research) that the Ma.Co.I is able to predict the quality of $\mathrm{ABR}$ and help to the protection of investors.

The structure of the paper is as follows: Section 2 provides a brief introduction in the related literature in view of the banking sector and the quality of narrative reporting. Section 3 describes the methodology and the data sets, while setting the research questions. Section 4 analyses and interprets the outcomes of the examined questions, explicitly presenting the results. Section 5 summarizes the main implications and conclusions of the study.

\section{Literature Review}

\subsection{The Banking Sector}

During the last decade, a significant transformation has occurred in the financial environment. The key roles of the banking industry's operations are fierce competition, market liberalization, internalization and integration, technology expansion, development of new specialized financial products and growth of financial derivatives' market [7]. These challenges have led financial institutions to alter its operational context for effective deployment of all its prospects in the financial markets [8]. As mentioned [9], there is a strong association between the banks' liquidity provided and the measures of the economic activity. Consequently, the changes that banks promote in their financing policy and strategy have a vast impact not only to the Gross National Product (GNP) but also to other fundamental macroeconomic indicators that influence an economy's activity and wealth. Evidently, the potency and economic steadiness of the financial institutions play a critical role in national economies worldwide. On the one hand, a vigorous banking sector accelerates the economic growth of a nation. On the other hand, the financial instability in financial institutions causes numerous deficiencies in the macroeconomic level of a country [10].

Two of the ultimate missions of the financial institutions are considered to be the increase of shareholders' value and the attainment of profitability. Despite the fact that 
banks address plentiful, flexible and remarkable alternatives to individuals and enterprises, their main objective is the long term profitability to strengthen and guarantee future survival [11]. Financial institutions focus on financial results in order to cope with the entrance obstacles that new institutions face in the banking sector along with the intense competition of the existing ones. Earnings and profitability goes at the very heart of their existence, as they are used to cover numerous necessitates of the banks' image such as to "pay dividends to shareholders, to increase equity, to finance activities which improve the social profile and the brand name in the market share" [8] [12].

A report conducted by the [13] indicates that the effectiveness of the banking system is an area of great importance. However, during the banking sector's process of efficiency and competitiveness examination, obstacles arise from the intangible products and services which financial institutions provide into the markets [14]. A great diversity of bank performance measurement variables have been mentioned by numerous scholars, such as costs and efficiency factors. In the early of 80's, [15] introduced interest margin as an important dimension of accessing US commercial banks performance, calculating the interest income minus expenses and dividing it with total assets. In addition, [16], examined bank performance using a correlation analysis model which includes indexes of profitability, loan market share and the pricing policy of the bank services. Moreover, [17] investigated the technical efficiency of large banks. Their research indicated that larger banks exhibit a greater level of technical efficiency while operating under a diminishing amount of scale returns. Lastly, a research conducted by [18], emphasizes on the banks' size, concluding that it affects its efficiency.

[19] compared the regulated and deregulated markets, highlighted that in both type of markets, book value and earnings were strongly related with cost recovery, ROA, and security prices. As a result, both "asset capitalization" (BV) and "operational efficiencies" (earnings) tended to be key indicators in the market evaluation of the firm's future prosperity and security price.

In a research conducted by [12], a wide range of performance measures used by scholars and practitioners in banks were observed. The researchers made a distinction between "traditional, economic and market-based" measures of performance. The most important traditional measures of assessing financial performance are ROE and ROA. In addition, the study mentions that ROE and ROA are considered as important determinants of profitability and reflect the banks' performance. The Return on Assets (ROA) indicator represents how effectively a business has been using its operating assets while the Return on Equity (ROE) indicator is a measure of how well a company has "reinvested earnings to generate additional earnings".

Aside from the banks' financial performance, [20] highlights asymmetric information as another important dimension of the banks' financial operating scheme. According to the study, banks deal with asymmetric information conflicts not only when they lend to enterprises and evaluate their forthcoming forecasts, but also when they are intended to be borrowed from the financial markets. In this light, [21], mention that the increase in the quality of annual reports narrative portion play a key role in debt financing. 
[22] highlights the financial statements analysis as an important tool in presenting the financial position of an organisation. The financial statements analysis and valuation is essential due to a great diversity of groups (investors, public authorities, shareholders) who are interested in the stated financial results and the management comments concerning the prospects of banks' growth and vision. According to its application, each group analyses financial statements for different purposes and in different aspects of the presented annual or quarterly outcomes. As mentioned by [23], the accounting strategies managers' utilize, may affect the reported financial results of an enterprise. The latter, in conjunction with financial reporting disclosures, may raise opportunistic situations about the future forecasts of financial performance [8]. "The banks are disposed in liquidity and monetary fluctuation risks, changes in the interest rates and the danger of bankruptcy of the counterparties". These risks are reflected in the financial reporting disclosures where the management of banks states how is going to surpass the stated threats. As a result, the external parties have a clearer point of view about how banks will restructure their operations to avoid future hazards [24] [25].

\subsection{The Greek Banking Sector}

The Greek economy is characterized as bank-based. The Greek banks, operating as mediating institutions, offer a wide range of services extending from portfolio management and suitable saving opportunities to exceptional funding prospects not only to individuals but also to enterprises leading to modernization and growth alternatives [26] [27]. During the period 2002 to 2007, the Greek financial sector has developed dynamically and rapidly. The expansion of the Greek economy was steadily above the European average growth rates. In addition, the remarkable decrease of the interest rates as well as the privatizations in the Greek financial sector changed the competition variables, while engendering multiple benefits for the economy and the shareholders. Evidence from the Greek stock market highlights the performance of the banking sector, as the rates of growth were double in comparison with the other sectors [28].

The Greek financial institutions through their effort to take upon the opportunities engendered by the changes in the global and national financial sector were led to strategic co-operations based on mergers and acquisitions in order to strengthen their position in the market by developing large financial corporations. These actions have reinforced their capital structure, expanded their networks while the services they offered were more attractive to the potential customers [29].

Various scholars have focused on the factors which assess the performance and profitability of Greek banks. In 1995, [30] conducted a research for the period 1989-1991 relating to the release and performance of the Greek banking sector, concluding that the lead indicators of profitability were quite different from other countries because of the strong regulation in Greece. In addition, [27] performed a multi-criteria analysis to estimate the performance of banking sector using ratios analysis techniques during the period 1989-1992 basing on a utility model of Greek commercial banks to rank them. Furthermore, [31] investigated the competitiveness and effectiveness of the Greek financial institutions and highlighted that during the decade of 1990, the majority of me- 
dium sized financial institutions succeeded in a consistency of their profitability levels.

In addition, the financial crisis period (2008 to 2010), which originally broke out in the United States in autumn 2008 with the collapse of the Lehman Brothers investment bank, evolved into a global economic crisis as a consequence of interlinked globalized economies, causing the greatest recession period since the 1930s and a serious deterioration of public finances in most Western countries.

Especially since its dramatic deterioration in October 2008, the global financial crisis started to negatively affect the Greek economy and particular the Greek banking sector as well, leading to a considerable weakening of expectations in terms of liquidity and viability of the banking sector in general.

During the aforementioned period at least two issues are observed; first, the disclosure of narrative information in Greek banking sector's annual reports is not that easy to be read, due to complexity of the text that does exists within the financial statements and second, the information associated with risk and the strategy implemented by the banking institutions is not included in annual reports. These two problems were repeatedly highlighted by the Bank of Greece and international organizations as well in reports from the Governor of the Bank of Greece from 2008 to 2014, Dr. George Provoloulos. As a result, this research investigates the quality of narrative part of the Greek Banking Institutions' financial statements for the crisis period.

Most researches are based on survey derived quantitative factors taken from banks' financial statements characteristics and accounts. To the best of our knowledge survey is limited in the literature on the narrative qualitative information that banks include within their annual reports to assess their performance from a qualitative point of view. The current study intends to bridge the gap between the traditional examination of banks' performance and the up to date information derived from the narrative part of their financial reports.

\subsection{IFRS and the Quality of Financial Reports}

In the past years, the financial markets were in a diffusible and strict command of control where the state's interference on the banks' property and operations was potent. Some of the most important influential factors were the exogenous determination of rates, the binding commitments on deposits, and the credit control [7]. The mean of the asymmetric information between the interested parties concerning the banking sector was introduced by [32]. As they mentioned, the production of satisfactory information presented to the involved associates was critical in order to avoid the problem of moral hazards in the banking sector. [32] conducted a research based on the efficient information and how the latter adds value to the enterprises. According to the outcome of this research, the satisfactory presentation of critical information in the narrative part of the financial statements drives the increase of the banks' profits and liquidity [7].

In 2005, International Accounting Standards Board (IASB) introduced the IFRS reporting standards framework proposing the transition from the domestic accounting principles of European countries to the International Accounting Standards. One of the 
main reasons of the implementation of IFRS, as pointed out by [33], was the achievement of capital market integration. [34] noted that the benefits of the adoption of IFRS include "higher comparability data, lower transaction costs and greater international investment". In addition, [8] points out that IFRS also assists investors in making "informed financial decisions and predictions of firms' future financial performance and giving signal of higher quality accounting and transparency". Therefore, the IFRS would tend to decrease "earnings manipulation and improve stock market efficiency", while they would also tend to positively impact on firms stock returns and stock-related financial performance measures.

Worldwide, this fundamental change in the quality of corporate reporting is to be achieved by using further narrative information in annual reports, placing more emphasis on the management discussion and analysis statement in the annual reports. In some circumstances, for example, the regulators are extending and revising the guidelines, while in other cases, disclosures are becoming mandatory information; in the post-Enron period, MD\&A regulations are being strengthened (e.g., [35]) in the USA; in Canada, the Canadian Institute of Chartered Accountants (CICA) issued more detailed MD\&A guidelines and six disclosure principles are set out as well as a five-part integrated disclosure framework developed covering strategic, key performance drivers, capabilities, results and risks [36]. In the UK, the Accounting Standards Board issued revised OFR guidance which draws upon the Jenkins framework [37]. Finally, consideration of MC statements was put on the IASB agenda in 2002. An exceptional case between the countries mentioned above is Greece, since its financial reporting system does not follow a recognized set of Standards related to the presentation of narrative information. However, in the last ten years Greece has begun to adjust its local accounting standards (e.g.: General Accounting System-GAS) to the IFRS principles. In the light of this, it would be quite interesting to search for how Greek banks altered their practices and reporting quality on their annual reports focused on narrative part of information.

In addition, several studies attempt to evaluate the narrative reports with different methods. A great number of practitioners base this evaluation on a 'disclosure index'. [38], in a wide-known study, proposes an index to measure the voluntary disclosure level in 122 businesses in the machinery industry. [38] study was based on the narrative disclosures' analysis. The Canadian Institute of Chartered Accountants introduced the Jenkins Report [39] which sets, principally, the guidelines for the selection of items included in the analysis, and the study of the annual report. The categories of information were five: background information; summary of historical results; key non-financial statistics; projected information; and management discussion and analysis. This study included 35 major elements spread across the five categories.

\section{Research Methodology}

\subsection{Sample and Data}

Our study analyses the quality of the narrative reports of Greek commercial banks over 
the periods prior (2002-2004) and after (2005-2010) the implementation of the IFRS in Greece. The total number of Greek banks, operating in the whole period are 30 from which 14 commercial banks and 16 cooperative banks. Only 14 commercial banks were listed in the Athens Stock Exchange over the period 2002-2010. The total number of the listed commercial banks which were selected for the study is eleven (three banks excluded due to the lack of data availability). In order to evaluate the quality of the information disclosed in the MC, we gathered the appropriate financial reports of the banks from the Datastream database and the banks' official websites.

\subsection{Research Questions and Models}

The purpose of the current study is to explore the mandatory adoption of the IFRS and the quality of narrative reports. The four research questions that are to be examined are as follows:

Q1: Does the value relevance of earnings and book value have changed the stock price in Greek Banking Sector after the mandatory adoption of IFRS for the next 3 years?

Q2: Does the quality of the narrative part in Management Commentary (MC) of the ABR and the Key Financial Indicators have been improved after the next 3 years of mandatory adoption of IFRS?

Q3: Does the quality of narrative part (MC) of ABR changed during the crisis period (2008 to 2010)?

Q4: Is there a relation between the Key Financial Ratios and Quality of MC?

In order to answer the first research question, we will examine the hypothesis of how the IFRS adoption has changed the value of EPS and book value. The value relevance of book value and earnings provided under the Greek Accounting Standards (GAS) and the IFRS, suggesting that the IFRS facilitates higher narrative quality accounting information for investors in comparison to GAS [40]. Specifically, the IFRS propose that under these principles, the use of fair value measurements present more accurate not only a company's current thesis but also its future performance. As [21] argue, accounting amounts which reveal better a firm's underlying economics grant investors with important information assisting them in the decision making process. In this respect, the IFRS is considered to be a more investors-oriented regime. Alternatively, the GAS is principally oriented in the direction of stakeholders, with particular awareness to creditors. Thus, they tend to have a preference on traditional accounting practices to maintain capital upholding during the time. The model that was utilised to analyse the first research question is the OM which proposes a linear relation between price of a share (P), earnings per share (EPS) and book value per share (BV). The value which was used to calculate the price of a share was six months after the fiscal year to ensure that the corporate report and additional disclosures about the IFRS were available to investors as proposed by [2]. The dependent variable is considered to be $\mathrm{P}$, while the explanatory variables include BV and EPS, both measured on a per share basis, feeding the price-levels regression as follows: 


$$
P_{i t}=\alpha_{0}+\alpha_{1} B V_{i t}+\alpha_{2} E P S_{i t}+\varepsilon_{i t}
$$

where:

$P_{i t}$ is the price of a share of firm $i$ six months after the fiscal year-end $t$,

$\alpha_{0}$ : is the intercept term;

$B V_{i t}$ is the book value per share of firm $i$ at the end of the year $t$;

$E P S_{i t}$ is the earnings per share of firm $i$ for time period $t-1$ to $t$;

$\varepsilon_{i t}$ is the error term.

In order to thoroughly propose the second and third research question, we seek to rate the MC quality of the banks. The MC quality is defined as the amount of narrative information disclosed in the annual reports. The tool which was used to rate the amount of information disclosed in the annual reports, based on the Ma.Co.I proposed by the IASB (see, [5] [6]).

\subsection{The Management Commentary Index (Ma.Co.I)}

The Ma.Co.I provides the capacity to assess the disclosure quality of the firm's Management Commentary and to produce a quantitative value for that quality that might then be utilized as a part of further empirical analysis [6]. Our technique is implemented in two stages as depicted below:

First stage

We propose a new checklist called the Ma.Co.I that was developed for the detailed evaluation of financial reporting quality and was initially presented by the FASB and the IASB (for more details, see [5] [41]). The amount of narrative information revealed in an annual report is what determines an MC's quality. The Ma.Co.I includes of 37 constituent points that are classified into five categories as follows:

Category 1: The nature of the business

Category 2: Objective and strategy

Category 3: Key resources, risks and relationships

Category 4: Results and prospects

Category 5: Performance measures and indicators

These five categories are presented in Table A2, with their codes for the points and the number of points used in this research. The points selected after thoroughly consideration of MCF of 2010 which proposes specific guidelines that must be disclosed in Annual Report for maximizing the quality of information (see also Table A1 for details).

\section{Second stage}

In the second stage, we derived the Narrative information that was requested from the Final MCF given in 2010 using the points in Table A2.

The Ma.Co.I uses 70 KPIs for 37 points, taken by the MCF [5]. This was the case because some points require more than one KPI to cover the information suggested by the MCF. Therefore, the maximum quality score of the index is reached when the annual financial statement includes 70 KPIs. The information on the number of appropriate KPIs is given by the Factor Analysis method. Some points need more than one 
KPI to cover the appropriate amount of information (for example, refer to Table A3, where point 2 uses 3 KPIs). Furthermore, Table A3 proposes the final checklist of Ma.Co.I with 70 KPIs [6].

The disclosure score of the Ma.Co.I indicates the extent of disclosure compliance with the MCF. Based on this, a dichotomous scoring approach is applied by manually capturing each KPI's disclosure quality. If a required quality dimension is met, it is scored as one; otherwise, it is scored as zero. If a quality dimension is not applicable to a specific KPI, it is scored as 'not applicable' (NA) (e.g., [42] [43]). Consequently, the Ma.Co.I total disclosure score (denoted as $T$ ) is measured for each firm with the following formula:

$$
T=\sum_{i=1}^{m} d_{i}
$$

where: $d_{i}$ is the score of each KPI (" 1 " if the item is mentioned and " 0 " otherwise), and $\mathrm{m}$ is the maximum number of KPIs (70 disclosure items in total) that is expected to be disclosed by firms in compliance with MCF. The value of $\mathrm{T}$ depends on the number of KPIs disclosed by the firms. In addition, the quality and quantity score of the Ma.Co.I index for each firm lies between 0 and 100 or 0 and 70.

In addition, the mean of the main financial Indicators and ratios (ROE, ROA) of the two periods are compared in order to examine whether there is any change or not ([44] [45]).

In the Fourth research question, we attempted to investigate the relationship between the average of the key financial Indicators (ROE, ROA, Total Equity, Total Debt and Total Assets) and the Management Commentary score (MCs) utilizing the Spearman's rank correlation coefficient, a non-parametric index [46]. The scale of the Spearman's index $r$ lay in a range between -1 and 1 . If $r=-1$, the two variables examined are considered to be uncorrelated while $r=1$ stipulates complete correlation. The upper financial Indicators were selected because Total Equity, Total Debt and Total Assets are integral parts of Financial Statements and present the financial position of an organization; further, ROE and ROA evaluate the profitability and performance.

\section{Analysis}

\subsection{Ohlson Model}

The work of [2] had a profound impact on accounting research. What are the reasons for this enthusiasm for the Ohlson Model (OM)? A survey of the accounting literature reveals five possible reasons [46]. First, it appears that there is consensus among accounting researchers that one of the desirable properties of the $\mathrm{OM}$ is its formal linkage between valuation and accounting numbers. Second, researchers appreciate the versatility of the model [45] [46]. Third, the enthusiasm with the OM appears to be a response to [47] challenge that traditional approaches used in accounting research find a very weak linkage (low r-squared) between value changes and accounting information. Fourth, and related to the previous point, the high $r$-squared found in analyses that rely 
on the $\mathrm{OM}$ is interpreted to suggest that little value relevance is related to variables other than book value of equity, net income, and dividends. Moreover, the very high explanatory power of the models leads to conclude that the OM can be used for policy recommendations.

In Table 1, regression model results are presented for the period 2002-2004. With respect to analysing the outcomes for this period, it can be observed that the EPS has a positive relation with the $\mathrm{P}$ of a share six months after the fiscal year; BV has a negative relationship with the P (both EPS and BV are statistically significant different from zero).

Table 2 presents the results of the regression model for the period 2005-2007. According to the regression model, it can be noticed that the E and the BV positively affect the change of $\mathrm{P}$ six months after the fiscal year (both variables are significant).

The results produced in Table 1 are not consistent to answer our hypothesis therefore we will investigate the validity of the model presented in Table 2, which assumes a linear relationship between P, BV and EPS after the adoption of the IFRS. Various diagnostic tests were performed to establish goodness of fit and appropriateness of the model. First, it was examined as if there was multicollinearity in the model.

Also, the outcome of Table 1 and Table 2 indicates that BV and EPS have a positive correlation not only with $\mathrm{P}$ but also with each other during the examined period. In addition, we find that the correlation between the three variables tend to be increased after the implementation of IFRS. Moreover, we report that there is a greater amount of correlation among earnings and the other two variables.

\subsection{Quality of Narrative Information and Financial Indicators}

Research on the quality of the narrative part of the annual banking reports (ABR) has

Table 1. OLS Model 2002-2004 (Dependent Variable: P).

\begin{tabular}{ccccc}
\hline Variable & Coefficient & Std. Error & t-Statistic & Prob. \\
\hline C & 3.42 & 0.35 & 9.72 & $0.00^{*}$ \\
-EPS & 0.80 & 0.15 & 5.17 & $0.00^{*}$ \\
-BV & -0.06 & 0.03 & -1.78 & $0.08^{*}$ \\
\hline
\end{tabular}

Notes: R-squared $=0.582$, Adjusted R-squared $=0.545$, Durbin-Watson stat $=1.69$, F-statistic $=1.60$, Prob (F-statistic) $=0.000,{ }^{*}$ denotes significance.

Table 2. OLS Model 2005-2007 (Dependent variable: P).

\begin{tabular}{ccccc}
\hline Variable & Coefficient & Std. Error & t-Statistic & Prob. \\
\hline C & 10.74 & 4.64 & 2.31 & $0.03^{*}$ \\
EPS & 6.82 & 1.68 & 4.06 & $0.00^{*}$ \\
-BV & 6.52 & 2.95 & 2.21 & $0.04^{*}$ \\
\hline
\end{tabular}

Notes: R-squared=0.72, Adjusted R-squared=0.70, Durbin-Watson stat=1.49, F-statistic $=32.94$, Prob $($ F-statistic $)=$ $0.0000,{ }^{*}$ denotes significance. 
long been hampered by lack of tools that permit an objective analysis of qualitative disclosure. Thus, despite the continued demand for better comparability in financial re-porting practices, in our sample, a large number of Greek Banking Institutions do not seem to converge toward a single set of standards for both the narrative and financial disclosure.

Table 3 presents the descriptive statistics of the MC quality score based on the Ma.Co.I. For the financial reports of the eleven (11) banks, the narrative reporting quality has been considerably improved. To be more specific, the mean of the MC score of the financial reports narrative part prepared under Greek Accounting Standards (GAS) was $49 \%$, while under the IFRS had reached $68 \%$, a growth of approximately $39 \%$ in the mean MC score. In addition, the maximum level of narrative reporting quality for the period 2002-2004 was 0.81, while during 2005-2007, it increased to 0.90 . Conversely, the minimum amount of narrative reporting quality after the adoption of the IFRS is 0.32 , while during the pre-IFRS period was only 0.02 . These Indicators point out the reporting quality enhancement in the IFRS era with relation to the GAS era. The latter is also depicted in the decrease of the standard deviation from 0.244 to 0.165 , which indicates that the data points tend to be very close to the mean, with lower variability as well. In addition, the asymmetry of the probability distribution (skewness) has been decreased as well as the kurtosis has been extremely regularized from 2.5 to 2.04; therefore, the quality of financial reporting has been normalized between the 11 banks, attaining higher levels. Overall, the quality of MC was significantly improved in the IFRS period vs the GAS period, stating the Greek Banking System became better in terms of financial statements disclosure and quality in general.

In Table 4, the frequencies of MC scores are presented. The rows of the table present the number of the narrative quality reports for the period before the adoption of IFRS, while the columns present the equivalent numbers for the period after the IFRS adoption in Greece. The total of the 3-year narrative reports for each of the 11 banks before and after the IFRS implementation are categorized according to their MC scores.

In addition, during the GAS period, the MC scores of the 33 reports have been

Table 3. Descriptive statistics of MC quality.

\begin{tabular}{ccc}
\hline & GAS 2002-2004 & IFRS 2005-2007 \\
\hline Mean & 0.487879 & 0.676061 \\
Median & 0.58 & 0.68 \\
Maximum & 0.81 & 0.9 \\
Minimum & 0.02 & 0.32 \\
Std. Dev. & 0.244576 & 0.165358 \\
Skewness & -0.819579 & -0.430442 \\
Kurtosis & 2.500333 & 2.042475 \\
\hline
\end{tabular}


Table 4. Descriptive statistics of MC quality.

\begin{tabular}{cccccccc}
\hline \multirow{7}{*}{ Count } & \multicolumn{7}{c}{ GAS_02_04 } \\
\cline { 2 - 7 } & {$[0,0.2)$} & {$[0.2,0.4)$} & {$[0.4,0.6)$} & {$[0.6,0.8)$} & {$[0.8,1)$} & Total \\
\hline & {$[0.2,0.4)$} & 0 & 0 & 1 & 0 & 0 & 1 \\
IFRS_05_07 & {$[0.4,0.6)$} & 1 & 2 & 4 & 2 & 0 & 9 \\
& {$[0.6,0.8)$} & 4 & 2 & 3 & 2 & 0 & 11 \\
& {$[0.8,1)$} & 0 & 0 & 3 & 8 & 1 & 12 \\
& Total & 5 & 4 & 11 & 12 & 1 & 33 \\
\hline
\end{tabular}

spread out from very low levels of MC score (approximately 0 ) to high levels of 0.81 ( $81 \%$ of quality). The accumulation is observed between 0.30 and 0.80 with the higher percentage to be included in the intervals $[0.4,0.60)$ and $[0.6,0.8)$.

On the contrary, in the period after the implementation of IFRS, there is normalisation of differences between "good" and "bad" narrative quality information disclosed, while the mean has been displaced in higher levels of quality information outputs with an increasing dispersion in the intervals $[0.6,0.8)$ and $[0.8,1)$ therefore indicating improvement of narrative reporting quality and an alternation of the financial reporting orientation of the banks.

Figure 1 diagrammatically compares the MC quality score of the Greek banks between the two periods (2002-2004 and 2005-2007).

Table 5 that follows presents the improvement of management commentary quality. In analysing more extensively the results, three are the institutions with the highest positive impact on their financial reporting quality: increased its reporting quality from $24.67 \%$ to $60.67 \%$ a growth of $146 \%$. In addition, Bank \#9 raised its reporting quality by $125 \%$ despite the fact that it has the lowest level of reporting quality in comparison with the other banks. Finally, Bank \#3 improved its MC by approximately $106 \%$. Banks with the highest percentage of MC prior the implementation of the IFRS (2002-2004) had a steadily progress, such as Bank 10 (6.49\%), Bank \#5 (29.03\%), Bank \#8 (14.62\%) and Bank \#7 (44.44\%) reaching in reporting quality outputs over $80 \%$. The lowest amount of MC of the period 2005-2007 has been observed both in Banks \#4 and \#6 with a percentage of $49.67 \%$ and $53 \%$ respectively, without significant improvement of quality between the two periods.

Table 5 is taken form [7] research which used the Ma.Co.I for measuring the quality of Management Commentary score (MCs) for the eleven (11) Greek banks and we add in a separate row the ranking of banks. The outcome of this deed is truly innovative result, where actually the first 3 positions (and in correct sequence) are the banks that provide the best disclosure quality of narrative information (as Ma.Co.I stated) which totally consort with the ranking of best Greek banks according to Bank of Greece in 


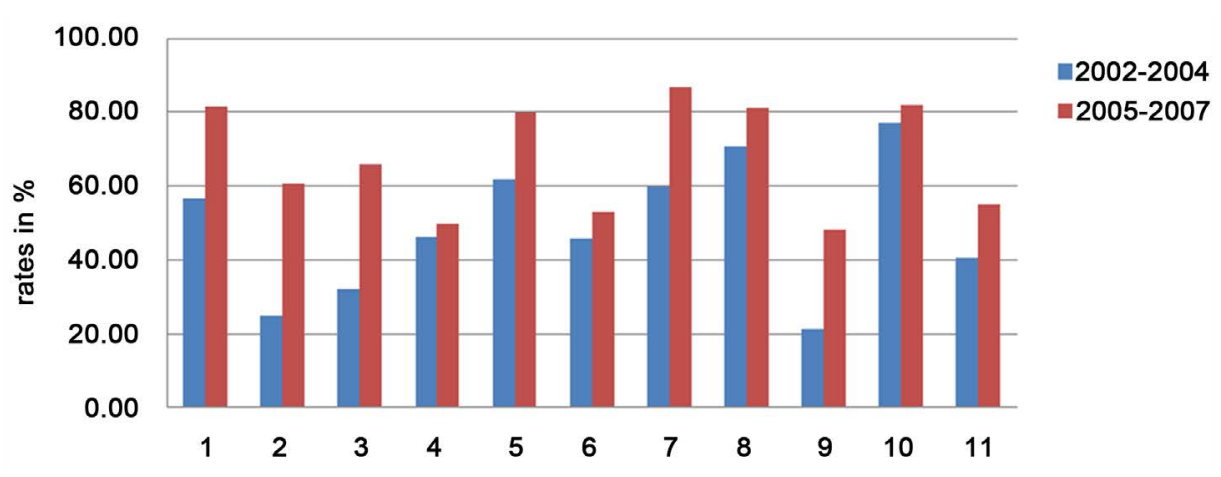

Figure 1. Average MC Scores of Greek banks, during the 2 periods (years 2002-2004) and (years 2005-2007).

Table 5. MC scores of the Greek banks for the pre- and after-IFRS implementation periods (source: Dimitras et.al 2013).

\begin{tabular}{lccc}
\hline \multicolumn{1}{c}{ BANK\# } & MCs Average 2002-2004 & MCs Average 2005-2007 & $\begin{array}{c}\text { Bank Ranking after } \\
\text { IFRS Adoption }\end{array}$ \\
\hline 1-ALPHA BANK & $56.67 \%$ & $81.67 \%$ & 3 \\
2-ATE BANK & $24.67 \%$ & $60.67 \%$ & 7 \\
3-ATTICA BANK & $32.00 \%$ & $66.00 \%$ & 6 \\
4-BANK OF CYPRUS & $46.03 \%$ & $49.67 \%$ & 10 \\
5-EMPORIKI BANK & $62.00 \%$ & $80.00 \%$ & 5 \\
6-NBG & $45.67 \%$ & $53.00 \%$ & 1 \\
7-EUROBANK & $60.00 \%$ & $86.67 \%$ & 4 \\
8-GENERAL & $70.67 \%$ & $81.00 \%$ & 11 \\
9-MARFIN BANK & $21.33 \%$ & $48.00 \%$ & 2 \\
10-PIRAEUS BANK & $77.00 \%$ & $82.00 \%$ & 8 \\
11-T BANK & $40.67 \%$ & $55.00 \%$ & 11 \\
Total Mean & $48.79 \%$ & $67.61 \%$ & \\
\hline
\end{tabular}

2010. An important innovative characteristic of the above results is that the Management Commentary Index (Ma.Co.I) is able to measure the actual quality and reliability of the banks financial statements and proposed the ranking of them.

Furthermore, in Table 6, Mergers and Acquisitions between banking Institutions are depicted with the positions these banking institutions hold during the period 2005-2007 according to their quality disclosers in their financial statements. The only banking institution that it was not engaged in banks Mergers and Acquisitions is the National Bank of Greece (NBG), where in contrast to the results of Ma.Co.I for the year 2013 (which were very low), considered by many as the best banking group for this period. Also, and for this case, Ma.Co.I index correctly predicted the quality of the MC information. In our estimation this is the reason where there was not a serious proposal for 
Table 6. Mergers and Acquisitions in the Greek Banking System (source: [48]).

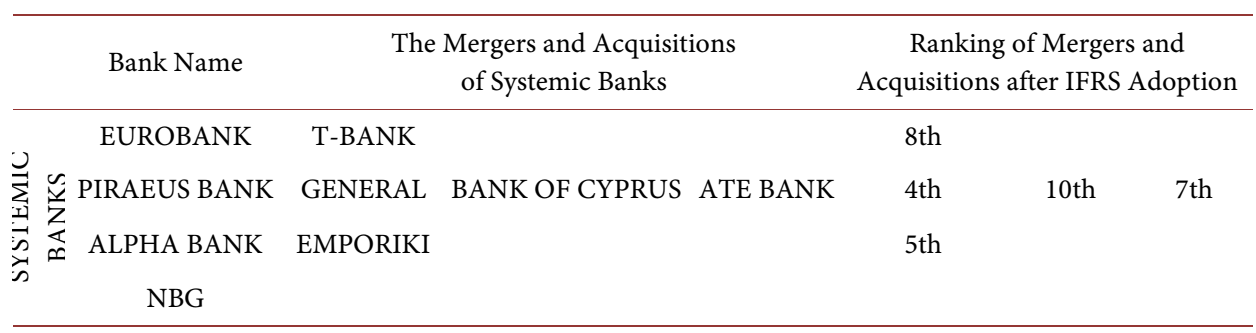

merging of NBG with another banking group so far. This shows that the quality of disclosure of narrative information was very important case for reek Banking Institutions and still remains.

As a result, taking into account the information provided in the above tables, we observe the following core characteristics:

1) It is demonstrated in practice that the more quality in narrative information does exists in an organization's financial statements, the more the investors trust and invest with less risk in this organization, enhancing therefore terms of profitability and sustainability of its business.

2) In addition, we observe that the Bank \#3 is ranked in the 6th place and thus did survived on the banking scene, despite significant changes in the ranking of Greek Banking Institutions as [7] express in their research, remaining active until today, although it is not included in the systemic banks.

3) Unlike the above, Bank \#9 where it ranked in the last place, we find it today being the only one from the list that has been driven into bankruptcy. Also in this case, the Ma.Co.I provided accurate information even before three years ago.

\subsubsection{Financial Indicators Trend Analysis}

The trends analysis of financial ratios Return on Equity (ROE) and Return on Assets (ROA) between the two periods (Figure 2) show that the banks' mean ROE improved approximately by $219 \%$. At the same time, there is a positive change of the mean ROA from 0.433 to 1.06 which is translated into a growth of $144.47 \%$.

The results of the trend analysis between the two periods highlighted the following (Figure 3): the Total Equity of the Greek banks appears to be increased from 906, 52 millions of $€$ to 1.68558 , a raise of $85.94 \%$. Furthermore, there is an increase in Total Debt from 2.17264 to 3.65703 millions of $€$.

Finally, it becomes apparent that after the IFRS adoption, banks have increased their Total Assets from 17.190,855 millions of $€$ to 27.499,640, which consists an increase of approximately $60 \%$. As the results we indicate, the main financial ratios of the eleven (11) Greek banks that have been evidently improved, assuming a positive impact after their transition from GAS to IFRS.

\subsubsection{Disclosure Quality of Narrative Information in Greek Crisis Period}

In Table 7, for the 2nd (years 2005-2007) and the 3rd period (years 2008-2010) we observe that the Bank \#7 ranks first in the list, the Bank \#9 takes the lowest ranking in 


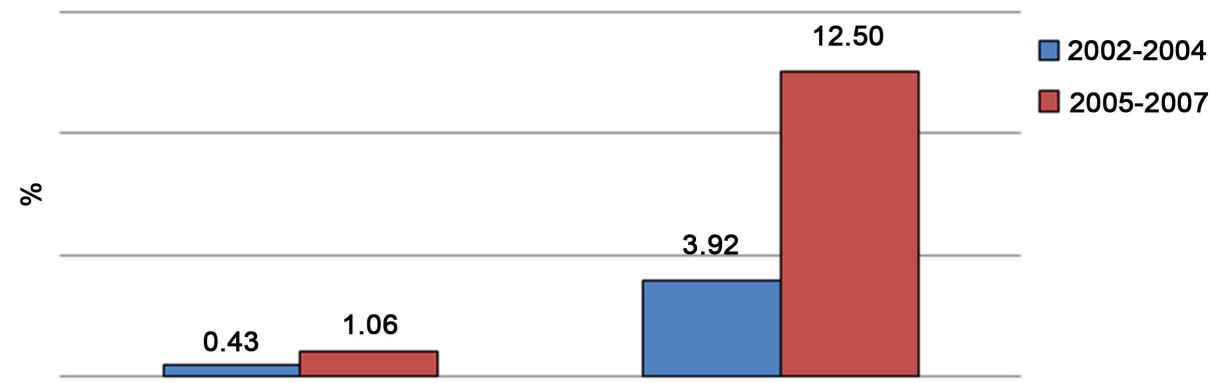

Figure 2. Change of average ROE and ROA respectively between the periods prior and after the implementation of IFRS.

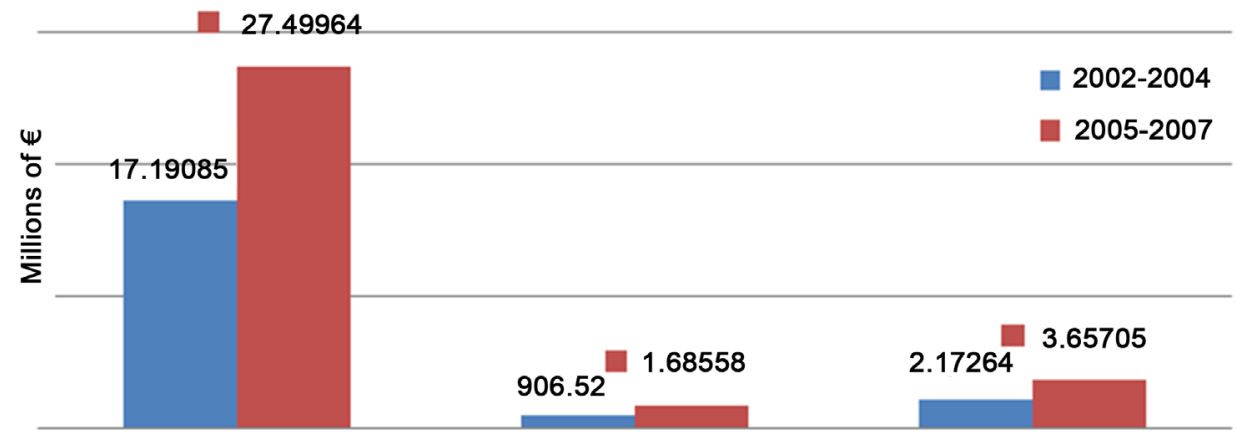

Figure 3. Change of average key financial Indicators between the periods prior and after the implementation of IFRS.

Table 7. MC scores of the Greek banks for the years 2002 to 2010.

\begin{tabular}{|c|c|c|c|c|c|c|}
\hline BANK\# & $\begin{array}{l}\text { Average of } \\
\text { 2002-2004 } \\
\text { MCs Quality } \\
\text { (1st period) }\end{array}$ & $\begin{array}{l}\text { Average of } \\
\text { 2005-2007 } \\
\text { MCs Quality } \\
\text { (2nd period) }\end{array}$ & $\begin{array}{c}\text { Average of } \\
\text { 2008-2010 } \\
\text { MCs Quality } \\
\text { (3rd period) }\end{array}$ & $\begin{array}{c}\text { Bank } \\
\text { Ranking } \\
\text { at } 3 r d \\
\text { period }\end{array}$ & $\begin{array}{c}\text { Differences } \\
\text { of MCs } \\
\text { Quality } \\
\text { between } \\
\text { 1st and 2nd } \\
\text { period }\end{array}$ & $\begin{array}{c}\text { Differences } \\
\text { of MCs } \\
\text { Quality } \\
\text { between } \\
\text { 2nd and 3rd } \\
\text { period }\end{array}$ \\
\hline 1-ALPHA BANK & $56.67 \%$ & $81.67 \%$ & $81.00 \%$ & 3 & $25 \%$ & $-0.67 \%$ \\
\hline 2-ATE BANK & $24.67 \%$ & $60.67 \%$ & $58.50 \%$ & 8 & $36 \%$ & $-2.17 \%$ \\
\hline 3-ATTICA BANK & $32.00 \%$ & $66.00 \%$ & $58.00 \%$ & 9 & $34 \%$ & $-8 \%$ \\
\hline 4-BANK OF CYPRUS & $46.03 \%$ & $49.67 \%$ & $44.50 \%$ & 10 & $3.64 \%$ & $-5.17 \%$ \\
\hline 5-EMPORIKI BANK & $62.00 \%$ & $80.00 \%$ & $70.00 \%$ & 6 & $18 \%$ & $-10 \%$ \\
\hline $6-\mathrm{NBG}$ & $45.67 \%$ & $53.00 \%$ & $71.00 \%$ & 4 & $7.33 \%$ & $18 \%$ \\
\hline 7-EUROBANK & $60.00 \%$ & $86.67 \%$ & $86.60 \%$ & 1 & $26.67 \%$ & $-0.07 \%$ \\
\hline 8-GENERAL & $70.67 \%$ & $81.00 \%$ & $70.67 \%$ & 5 & $10.33 \%$ & $-10.33 \%$ \\
\hline 9-MARFIN BANK & $21.33 \%$ & $48.00 \%$ & $42.00 \%$ & 11 & $26.67 \%$ & $-6 \%$ \\
\hline 10-PIRAEUS BANK & $77.00 \%$ & $82.00 \%$ & $86.50 \%$ & 2 & $5 \%$ & $4.50 \%$ \\
\hline 11-T BANK & $40.67 \%$ & $55.00 \%$ & $59.00 \%$ & 7 & $14.33 \%$ & $4 \%$ \\
\hline Total Mean & $48.79 \%$ & $67.61 \%$ & $66,16 \%$ & 11 & $18.82 \%$ & $-1.45 \%$ \\
\hline
\end{tabular}


relation to the quality of the information provided in its financial statements; the same also happens with the Bank \#4 which was led to bankruptcy and acquisition by Bank $\# 10$ in the coming years.

Moreover, we observe that overall quality in information provided in financial statements improved by $18.82 \%$ between the first (year 2002-2004) and second period (years 2005-2007), but it this trend didn't continued during the third reporting period (economic crisis years 2008-2010), that marked a reduction in absolute numbers of about $1.45 \%$. So, the beginning crisis period tended to affect the Greek Banks with the lower quality of narrative information.

\subsection{Spearman's Correlation Coefficient}

The final stage of the current research focused on the assessment that the financial Indicators affect mainly the narrative reporting quality of the two periods. The sample size used was the eleven banks $(n=11)$. Table 8 examines the correlation of average of financial Indicators with MC before and after the implementation of the IFRS, testing the following variables: Total Equity, Total Debt, Total Assets, ROA and ROE. It is worth highlighting that during the Greek Accounting Standards period, none of the five indicators seem to have a strong correlation with MC.

Conversely, under the IFRS principles, it has been observed that Total Debt has a strong correlation with MC with a correlation coefficient of 0.69 indicating a satisfactory level of significance between $5 \%$ and $1 \%$ according to the Spearman's scoring. This could be explained by the interest of the investors in MC quality in the recent years that made the Greek banks maintain a higher MC quality in order to support their high leverage policy. This phenomenon has to be further investigated in the light of newer data on MC quality and leverage in order to examine further this relation.

\section{Conclusions}

The current research adds new insight related to the quality and the form of narrative reporting in the business sector to the existing literature. Various scholars have attempted to analyse the narrative portion of financial statements, however, the results presented a theoretical basis of assessment. In this study, a quantitative approach of the qualitative data adopted using the Ma.Co.I. Therefore, we believe that this study would commence a more systematic approach of evaluating the narrative reporting that orga-

Table 8. Spearman's correlation coefficient of the average financial Indicators with MC in the pre- and post-IFRS implementation period.

\begin{tabular}{ccc}
\hline VARIABLES & $2002-2004$ & $2005-2007$ \\
\hline ROA-MC & -0.10 & 0.15 \\
ROE-MC & -0.06 & 0.15 \\
Total Assets-MC & 0.26 & 0.28 \\
Total Equity-MC & 0.32 & 0.26 \\
Total Debt-MC & 0.27 & 0.69 \\
\hline
\end{tabular}


nisations address for internal and external use.

The purpose of the current research was to examine the periods prior and after the implementation of the IFRS while focusing on the effects on the Greek commercial banks' financial and narrative reporting [49] [50]. Firstly, the present study investigates how the value relevance of earnings and book value has changed between the two periods. The Ohlson model has been utilized proposing a linear relationship between $\mathrm{P}$, $\mathrm{BV}$ and EPS measured on a per share basis. The regression model points out that the $\mathrm{P}$ has been positively affected by BV and EPS after the implementation of the IFRS principles in contrast with the period before the IFRS where there was not any linear relationship between P, BV and EPS. Secondly, the current paper examines the change of the narrative reporting quality of the banks while inspecting the key financial figure trends between the two periods. The results clearly show that MC of the Greek banks has been considerably improved after the adoption of IFRS. Furthermore, it has been proved that there is a positive impact of the selected financial ratios and Accounts (ROE, ROA, Total Assets, Total Equity and Total Debt) for the transition of GAS to IFRS. Evidence indicates that Total Debt with a level of significance 0.69 tends to have a strong relation with MC quality in the period after the implementation of the IFRS, while other financial Indicators of the study do not appear to have a strong relation with MC neither prior nor after the implementation of IFRS. Moreover, the beginning of Greek crisis period seems to affect the disclosure quality of narrative part of ABR in addition to two previous periods. Finally, an important innovative characteristic of the above results is that the Management Commentary Index (Ma.Co.I) is able to measure the actual quality and reliability of the banks financial statements and proposed the ranking of them.

\section{References}

[1] IASB (2005) Management Commentary. Discussion Paper, International Accounting Standards Board, London.

[2] Ohlson, J.A. (1995) Earnings, Book Values, and Dividends in Equity Valuation. Contemporary Accounting Research, 11, 661-678. http://dx.doi.org/10.1111/j.1911-3846.1995.tb00461.x

[3] Ely, K. and Waymire, G. (1996) Accounting Standard-Setting Organizations and Earnings Relevance. Working Paper, Emory University, Atlanta.

[4] Francis, J. and Schipper, K. (1996) Have Financial Statements Lost Their Relevance? Working Paper, University of Chicago, Chicago.

[5] IASB (2010) IFRS Practice Statement Management Commentary: A Framework for Presentation.

[6] Garefalakis, A., Dimitras, A., Floros, C. and Lemonakis, C. (2016) How Narrative Information Changed the Business World: Providing a New Measurement Tool. Corporate Ownership and Control, 13, 317-334.

[7] Dimitras, A., Garefalakis, A. and Zisis, P. (2013) The Effect of the IFRS Implementation on the Narrative Part of the Financial Reporting an Investigation of the Greek Banking Sector. International Research Journal of Finance and Economics, No. 104, 130-144.

[8] Iatridis, G. (2010) IFRS Adoption and Financial Statement Effects: The UK Case. Interna- 
tional Research Journal of Finance and Economics, 38, 165-172.

[9] Bernanke, B. and Blinder, A. (1992) The Federal Funds Rate and the Channels of Monetary Transmission. American Economic Review, 82, 901-921.

[10] Kashyap, K. and Stein, J. (1994) Monetary Policy and Bank Lending. In: Monetary Policy, Mankiw, N.G., Ed., University of Chicago Press, Chicago.

[11] Drehmann, M. and Tarashev, N. (2011) Measuring the Systemic Importance of Interconnected Banks. BIS Working Papers, No. 342.

[12] Gilbert, A. and Wheelock, D. (2007) Measuring Commercial Bank Profitability: Proceed with Caution. Federal Reserve Bank of St. Louis Review, November/December 2007.

[13] European Central Bank (ECB) (2010) Beyond ROE-How to Measure Bank Performance. Report on EU Banking Structures, ECB September 2010.

[14] Kosmidou, K. and Zopounidis, C. (2008) Measurement of Bank Performance in Greece. South-Eastern Europe Journal of Economics, 6, 79-95.

[15] Revell, J. (1980) Costs and Margins in Banking: An International Survey. OECD, Paris.

[16] Arshadi, N. and Lawrence, E.C. (1987) An Empirical Investigation of New Bank Performance. Journal of Banking and Finance, 11, 33-48. http://dx.doi.org/10.1016/0378-4266(87)90020-3

[17] Miller, S. and Noulas, A. (1996) The Technical Efficiency of Large Banks Production. Journal of Banking and Finance, 20, 495-509. http://dx.doi.org/10.1016/0378-4266(95)00017-8

[18] Miller, S. and Noulas, A. (1997) Portfolio Mix and Large-Bank Profitability in the USA. Applied Economics, 29, 505-512. http://dx.doi.org/10.1080/000368497326994

[19] El-Gazzar, S., Finn, P. and Tang, C. (2006) The Relative Importance of Earnings and Book Value in Regulated and Deregulated Markets: The Case of the Airline Industry. Faculty Working Papers, Lubin School of Business, New York.

[20] Watts, R. (2003) Conservatism in Accounting Part I: Explanations and Implications. Accounting Horizons, 17, 207-221. http://dx.doi.org/10.2308/acch.2003.17.3.207

[21] Barth, E., Landsman, W. and Lang, M. (2008) International Accounting Standards and Accounting Quality. Journal of Accounting Research, 46, 467-498.

http://dx.doi.org/10.1111/j.1475-679X.2008.00287.x

[22] Tarca, A. (2004) International Convergence of Accounting Practices: Choosing between IAS and U.S. GAAP. Journal of International Financial Management and Accounting, 15, 60-91. http://dx.doi.org/10.1111/j.1467-646X.2004.00102.x

[23] Lundstrum, L. (2003) Firm Value, Information Problems and the Internal Capital Market. Review of Quantitative Finance and Accounting, 21, 141-156. http://dx.doi.org/10.1023/A:1024839432369

[24] Rochet, J. and Vives, X. (2004) Coordination Failures and the Lender of Last Resort: Was Bagehot Right after All? Journal of the European Economic Association, 2, 1116-1147. http://dx.doi.org/10.1162/1542476042813850

[25] Goldstein, I. and Pauzner, A. (2005) Demand-Deposit Contracts and the Probability of Bank Runs. Journal of Finance, 60, 1293-1327. http://dx.doi.org/10.1111/j.1540-6261.2005.00762.x

[26] Zopounidis, K., Despotis, K. and Stavropoulou, E. (1995) Multiattribute Evaluation of Greek Banking Performance. Applied Stochastic Models and Data Analysis, 11, 97-107. http://dx.doi.org/10.1002/asm.3150110110

[27] Pasiouras, P and Zopounidis, C. (2008) Consolidation in the Greek Banking Industry: Which Banks Are Acquired? Managerial Finance, 34, 198-213. 
[28] IMF (International Monetary Fund) (2006) Greece: Financial System Stability Assessment, including Reports on the Observance of Standards and Codes on the following Topics, Banking Supervision, Insurance Supervision, Securities Regulation, and Anti-Money Laundering and Combating the Financing of Terrorism. IMF Country Report No. 06/6, January 2006.

[29] Eichengreen, B. and Gibson, H. (2001) Greek Banking at the Dawn of the New Millennium. CEPR Discussion Paper, No. 2791.

[30] Alexakis, P., Thomadakis, S. and Xanthakis, M. (1995) Banks Liberalization and Profitability: Evidence from Greek Commercial Banks. Journal of International Financial Markets, Institutions and Money, 5, 181-192.

[31] Hardy, D. and Simigiannis, G. (1998) Competitiveness and Effectiveness of the Greek Banking System. Economic Review of the Bank of Greece, 11, 7-30.

[32] Campbell, T. and Kracaw, W. (1980) Information Production, Market Signalling, and the Theory of Financial Intermediation. Journal of Finance, 35, 863-882. http://dx.doi.org/10.2307/2327206

[33] Armstrong, C., Barth, M., Jagolinzer, A. and Riedl, F. (2009) Market Reaction to the Adoption of IFRS in Europe. The Accounting Review. http://papers.ssrn.com/sol3/papers.cfm?abstract_id=903429

[34] Florou, A. and Kosi, U. (2009) The Economic Consequences of Mandatory IFRS Adoption for Debt Financing. Marie Curie Research Training Network: The IFRS Revolution: Compliance, Consequences and Policy Lessons, INTACCT.

[35] SEC (Securities and Exchange Commission) (1968) Securities Act Release. No. 4936, 9 December.

[36] CICA (2002) Management's Discussion and Analysis: Guidance on Preparation and Disclosure. Canadian Institute of Chartered Accountants, Ontario.

[37] ASB (2003) Operating and Financial Review. Accounting Standards Board, London.

[38] Botosan, C.A. (1997) Disclosure Level and the Cost of Equity Capital. The Accounting Review, 72, 323-349.

[39] AICPA (1994) Improving Business Reporting-A Customer Focus: Meeting the Information Needs of Investors and Creditors, Comprehensive Report of the Special Committee on Financial Reporting. The Jenkins Report, American Institute of Certified Public Accountants, New York.

[40] Seah, S.S.Y. and Tarca, A. (2006) An Investigation of International Comparability of Management Discussion and Analysis Reports. AFAANZ.

[41] Holder-Webb, L., Jeffrey, R.C., Leda, N. and Wood, D. (2007) The Supply of Corporate Social Responsibility Disclosures among U.S. Firms. Journal of Business Ethics, 84, 497-527. http://dx.doi.org/10.1007/s10551-008-9721-4

[42] Cooke, T.E. (1989) An Empirical Study of Financial Disclosure by Swedish Companies. Garland, New York.

[43] Cooke, T.E. (1992) The Impact of Size, Stock Market Listing and Industry Type on Disclosure in the Annual Reports of Japanese Listed Companies. Accounting and Business Research, 22, 229-237. http://dx.doi.org/10.1080/00014788.1992.9729440

[44] Noulas, A. (1999) Profitability and Efficiency of the Greek Banks (1993-1998). Journal of the Banking Association of Greece, 19, 53-60.

[45] Staikouras, C. and Steliaros, M. (1999) Determinants Factors of Profitability of the Greek Banking System. Journal of the Banking Association of Greece, 19, 61-66. 
[46] Lo, K. and Lys, T.Z. (2000) The Ohlson Model: Contribution to Valuation Theory, Limitations, and Empirical Applications. Sauder School of Business Working Paper. http://ssrn.com/abstract $=210948$

[47] Ljung, G.M. and Box, G.E.P. (1978) On a Measure of Lack of Fit in Time Series Models. Biometrika, 65, 297-303. http://dx.doi.org/10.1093/biomet/65.2.297

[48] Bank of Greece (2010) The Greek Economy Stabilisation Programme: Main Points on the Support Mechanism, Mimeo.

[49] Garefalakis, A., Lappa, E., Mantalis, G., Xanthos, G. and Alexopoulos, G. (2015) Is the Adoption of IFRS, an Essential Element Concerning the Mediterranean European Union's Banks? European Journal of Scientific Research, 136.

[50] Garefalakis, A., Lappa, E., Mantalis, G., Xanthos, G. and Spinthiropoulos, K. (2015) How IFRS Affects the Return on Asset? \& Is More Value Relevant Constructed Based on IFRS than Based on Local GAAP? International Research Journal of Finance and Economics, $142,122-131$ 


\section{Appendix}

Table A1. Coding in 37 major points the "ifrs practice statement management commentary" published by the IASB, 2010 pp $12-16$.

\begin{tabular}{|c|c|}
\hline No. of Points & Categories \\
\hline
\end{tabular}

Category 1: The nature of the business

Point $1 \quad$ (b) the entity's main markets and competitive position within those markets;

(c) significant features of the legal, regulatory and macro-economic environments that influence the entity and the markets in which the entity operates;

Point 2, Point 3

Point 4

(d) the entity's main products, services, business processes and distribution methods;

(e) the entity's structure and how it creates value.

\section{Category 2: Objective and strategy}

Point 5 , Point 7

Point 6

Point 8

Point 9, Point 10

Resources

Point 11, Point 12

Point 13 to Point 17

Risks

Point 18

Point 19

Point 20

Relationships

Point 21

Point 22
Management should disclose its objectives and strategies in a way that enables users of the financial reports to understand the priorities for action as well as to identify the resources that must be managed to deliver results. For example, information about how management intends to address market trends and the threats and opportunities those market trends represent provides users of the financial reports with insight that may shape their expectations about the entity's future performance.

Management should also explain how success will be measured and over what period of time it should be assessed.

Management should discuss significant changes in an entity's objectives and strategies from the previous period or periods.

Discussion of the relationship between objectives, strategy, management actions and executive remuneration is also helpful.

Category 3: Key resources, risks and relationships

Management commentary should set out the critical financial and non-financial resources available to the entity and how those resources are used in meeting management's stated objectives for the entity.

Disclosure about resources depends on the nature of the entity and on the industries in which the entity operates.

Analysis of the adequacy of the entity's capital structure, financial arrangements (whether or not recognized in the statement of financial position), liquidity and cash flows, and human and intellectual capital resources, as well as plans to address any surplus resources or identified and expected inadequacies, are examples of disclosures that can provide useful information.

Management should disclose an entity's principal risk exposures and changes in those risks, together with its plans and strategies for bearing or mitigating those risks, as well as disclosure of the effectiveness of its risk management strategies. This disclosure helps users to evaluate the entity's risks as well as its expected outcomes. Management should distinguish the principal risks and uncertainties facing the entity, rather than listing all possible risks and uncertainties.

Management should disclose its principal strategic, commercial, operational and financial risks, which are those that may significantly affect the entity's strategies and progress of the entity's value. The description of the principal risks facing the entity should cover both exposures to negative consequences and potential opportunities.

Management commentary provides useful information when it discusses the principal risks and uncertainties necessary to understand management's objectives and strategies for the entity. The principal risks and uncertainties can constitute either a significant external or internal risk to the entity.

Management should identify the significant relationships that the entity has with stakeholders, how those relationships are likely to affect the performance and value of the entity, and how those relationships are managed.

This type of disclosure helps users of the financial reports to understand how an entity's relationships influence the nature of its business and whether an entity's relationships expose the business to substantial risk. 


\section{Continued}

Results

Point 23, Point 24

Point 28

Point 25 to Point 27

Prospects

Point 30a

Point 29

Point 30b

Point 31, Point 32

Point 33a

Point 34

Point 37

Point 36

Point 33b

Point 35
Management commentary should include explanations of the performance and progress of the entity during the period and its position at the end of that period. Those explanations provide users of the financial reports with insight into the main trends and factors affecting the business.

In providing those explanations, management should describe the relationship between the entity's results, management's objectives and management's strategies for achieving those objectives.

In addition, management should provide discussion and analysis of significant changes in financial position, liquidity and performance compared with those of the previous period or periods, as this can help users to understand the extent to which past performance may be indicative of future performance.

Management should provide an analysis of the prospects of the entity, which may include targets for financial and non-financial measures.

This information can help users of the financial reports to understand how management intends to implement its strategies for the entity over the long term.

When targets are quantified, management should explain the risks and assumptions necessary for users to assess the likelihood of achieving those targets.

Category 5: performance measures and indicators

Performance measures are quantified measurements that reflect the critical success factors of an entity.

Indicators can be narrative evidence describing how the business is managed or quantified measures that provide indirect evidence of performance. Management should disclose performance measures and indicators (both financial and non-financial) that are used by management to assess progress against its stated objectives.

Management should explain why the results from performance measures have changed over the period or how the indicators have changed. This disclosure can help users of the financial reports assess the extent to which goals and objectives are being achieved.

The performance measures and indicators that are most important to understanding an entity are those that management uses to manage that entity. The performance measures and indicators will usually reflect the industry in which the entity operates.

Comparability is enhanced if the performance measures and indicators are accepted and used widely, either within an industry or more generally. Management should explain why the performance measures and indicators used are relevant.

Consistent reporting of performance measures and indicators increases the comparability of management commentary over time. However, management should consider whether the performance measures and indicators used in the previous period continue to be relevant.

As strategies and objectives change, management might decide that the performance measures and indicators presented in the previous period's management commentary are no longer relevant. When management changes the performance measures and indicators used, the changes should be identified and explained.

If information from the financial statements has been adjusted for inclusion in management commentary, that fact should be disclosed. If financial performance measures that are not required or defined by IFRSs are included within management commentary, those measures should be defined and explained, including an explanation of the relevance of the measure to users. When financial performance measures are derived or drawn from the financial statements, those measures should be reconciled to measures presented in the financial statements that have been prepared in accordance with IFRSs.

Table A2. Descriptions of 37 major points.

Codes of Points

Point 2

Point 3

Point 4

\section{Description of Points}

Category 1: Nature of the Business

Description of the nature of the business and business segments

Discussion of products

Discussion of business/board structure

Discussion of operating environment

Category 2: Objective and strategies 


\section{Continued}

Point 5

Point 6

Point 7

Point 8

Point 9

Point 10

Point 11

Point 12

Point 13

Point 14

Point 15

Point 16

Point 17

Point 18

Point 19

Point 20

Point 21

Point 22

Point 23

Point 24

Point 25

Point 26

Point 27

Point 28

Point 29

Point 30

Point 31

Point 32

Point 33

Point 34

Point 35

Point 36

Point 37
Discussion on financial objectives/strategies of the business

Time frame for achieving financial objective

How non-financial objectives monitoring and create or preserve value Significant changes in objectives and strategy

A strategy of the vision and value of the business

Discussion of how value \& objectives relates to strategy

Category 3: Key resources, risks and relationships

Discussion of key financial resources available to the company

Discussion of the key non-financial resources available to the company Adequancy of financial and non-financial resources

Analysis of capital structure

Analysis of financial arrangements

Discussion of liquidity and cash flows of the business

Plans to address any identified inadequacies or surplus of resources

Potential impact of the identified risks and how they are managed

Identification of key external and internal risks and opportunities

Explanation changes in risk management

Discussion of key relationship in place e.g. employees

How key relationships are managed and likely impact on business

Category 4: Results and prospects

Explanation of the development and performance of the entity during the year

Explanation of the financial position at the end of the year

Discussion of significant changes in financial position

Variability of quarterly sales over the last three years. AND Net Income growth (three-year annual growth).

Extent to which past results are indicative of future progress /results

The management of the firm set specific objectives and explain how to achieve them?

Analysis of improvements/prospects of the entity AND how implement its targets/strategies about future.

Identification of objectives/targets for non-financial measures

Category 5: Performance measures and indicators

Discussion of key financial measures used to measure and assess improvement progress

Discussion of key non-financial measures used to measure and assess progress

Changes in the quantified measures or indicators reported

Identification of key financial and non-financial indicators that it uses to monitor progress

Explanation of how each measure, or quantified indicator, reported in MC has been defined and calculated

Consistent reporting of performance measures and indicators

Discussion of the purpose of each reported measure should be disclosed 
Table A3. The Management Commentary Index (Ma.Co.I).

\begin{tabular}{|c|c|c|c|}
\hline $\begin{array}{l}\text { Number of } \\
\text { Points }\end{array}$ & Description of Points & $\begin{array}{l}\text { Number } \\
\text { of KPIs }\end{array}$ & Description of KPIs \\
\hline
\end{tabular}

\section{A. Nature of the Business}

Description of the nature of the business AND business segments

2

Discussion of products

3

Discussion of business/board structure

4

Discussion of operating environment

\section{B. Objective and strategies}

A detailed description of a company's operations.

It may include any or all of the following items:

A general comment concerning the company's type of business

(1) The size of the company, if relevant

(2) Number of offices, stores, restaurants

(3) Represent the Business line as reported by the company.

2

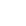

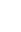

0
Does the company have a policy to protect customer health \& safety? AND Does the company have a products and services quality policy?

Does the company describe the implementation of its product responsibility policy?

Does the company monitor the impact of its products or services on consumers or the community more generally?

Does the company describe the implementation of its balanced board structure policy?

Does the company have a policy for ensuring equal treatment of minority shareholders, facilitating shareholder engagement or limiting the use of anti-takeover devices?

Does the company describe the implementation of its shareholder rights policy?

Does the company describe the implementation of its integrated strategy through a public commitment from a senior management or board member? AND Does the company describe the implementation of its integrated strategy through the establishment of a CSR committee or team?

The maximum time horizon of targets to reach compensation incentives.

Does the company monitor its integrated strategy through belonging to a specific sustainability index or conducting external audits on its reporting?

Does the company set specific objectives to be achieved on resource efficiency? AND Does the company comment on the results of previously set objectives?

Does the company have the necessary internal improvement and information tools to develop attractive and performance-oriented compensation policy?

Does the company have a policy for maintaining an overarching vision and strategy that integrates financial and extra-financial aspects of its business?

Does the company set specific objectives to be achieved on the integrated strategy?

\section{Key resources, risks and relationships}




\section{Continued}

Discussion of key financial resources available to the company

Discussion of the key non-financial resources available to the company business

Plans to address any identified inadequacies or surplus of resources

Potential impact of the identified risks and how they are managed

Identification of key external and internal risks and opportunities

Return on equity (ROE).

The company's credit rating as provided by Fitch (AAA (24 points); AA+ (23 points); AA (22 points); $A A-(21$ points); $A+(20$ points); $A$ (19 points); $A-(18$ points); $\mathrm{BBB}+(17$ points); $\mathrm{BBB}$ (16 points); $\mathrm{BBB}-(15$ points); $\mathrm{BB}+(14$ points); $\mathrm{BB}$ (13 points); $\mathrm{BB}-(12$ points); $\mathrm{B}+(11$ points); $\mathrm{B}$ (10 points); $\mathrm{B}-(9$ points $) ; \mathrm{CCC}+(8$ points); CCC (7 points); CCC - (6 points); CC+ (5 points);

CC (4 points); CC- (3 points); C (2 points); D (1 points); DD (1 points); DDD (1 points)).(26)

Net debt to equity.

Long-term debt to equity.

Retained earnings divided by equity.

Dividend payout ratio.

Does the company describe the implementation of its shareholder loyalty policy through a public commitment from a senior management or board member to avoid the misuse of inside information? AND Does the company describe the implementation of its shareholder loyalty policy by having the processes in place to avoid the misuse of inside information?

Does the company describe the implementation of its board functions policy?

Does the company describe the implementation of its compensation policy?

Does the company describe the implementation of its diversity and opportunity policy?

Does the company report about the challenges or opportunities linked to the integration of financial and extra-financial issues?

Return on invested capital (ROIC).

Average of the last five years of capital expenditures divided by sales.

Does the company set specific objectives to be achieved

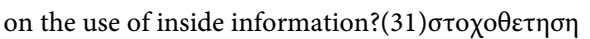

Operating cash flow (or unlevered free cash flow (UFCF)) growth (three-year annual growth).

Current ratio (Total Current Assets / Total Current Liabilities).

Does the company have a policy for reducing the use of natural resources? AND Does the company have a policy to lessen the environmental impact of its supply chain? Does the company claim to apply quality management systems, such as ISO 9000, Six Sigma, Lean Manufacturing, Lean Sigma, TQM or any other similar quality principles?

Does the company reports about take-back procedures and recycling programmes to reduce the potential risks of products entering the environment? OR Does the company report about product features and applications or services that will promote responsible, efficient, cost-effective and environmentally preferable use? 


\section{Continued}

Discussion of key relationship in place e.g em-

$$
\text { ployees }
$$

How key relationships are managed and likely impact on business
Analysis of improvements/prospects of the entity AND how implement its targets/strategies about future.

\section{Identification of objectives/targets for} non-financial measures
Does the company report on crisis management systems or reputation disaster recovery plans to reduce or minimize the effects of reputation disasters? Does the company have a policy for maintaining a loyal and productive employee base? Does the company describe the implementation of its employee satisfaction policy? Does the company monitor its reputation or its relations with communities?

Does the company have a competitive employee benefits policy or ensuring good employee relations within its supply chain? AND Does the company have a policy for maintaining long term employment growth and stability?

Does the company set specific objectives to be achieved on the employee satisfaction strategy?

Does the company have a policy for maintaining a well-balanced membership of the board?

Does the company have a policy to strive to be a good corporate citizen or endorse the Global Sullivan Principles? AND Does the company have a policy to respect business ethics or has the company signed the UN Global Compact or follow the OECD guidelines?

Does the company report data or studies which generally show improvements in the satisfaction and loyalty of its employees?

Has the company issued a profit warning during the year?

Does the company publish a separate CSR/H \& S/Sustainability report or publish a section in its annual report on CSR/H\&S/Sustainability?

Does the company's extra-financial report take into account of the global activities of the company?

Variability of quarterly sales over the last three years.

Is the management and board members remuneration partly linked to objectives or targets which are more than two years forward looking?

Does the company set specific objectives to be achieved on resource efficiency? AND Does the company comment on the results of previously set objectives?

Is the senior executive's compensation linked to $\mathrm{CSR} / \mathrm{H} \& \mathrm{~S} /$ Sustainability targets

Does the company have the necessary internal improvement and information tools to develop appropriate shareholder rights principles?

Does the company set specific objectives to be achieved on emission reduction?

Does the company set specific objectives to be achieved on its products or services quality and responsibility?

Does the company set specific objectives to be achieved on its reputation or its relations with communities?

Does the company set specific objectives to be achieved on employment quality? 


\section{Continued}

\section{E. Performance measures and indicators}

31 Discussion of key financial measures used to measure and assess improvement progress

Discussion of key non-financial measures used to measure and assess progress

33

Changes in the quantified measures or indicators reported

Identification of key financial and non-financial indicators that it uses to monitor progress

Explanation of how each measure, or quantified indicator, reported in MC has been defined and calculated

Consistent reporting of performance measures and indicators
Does the company report data or studies which generally show improvements in the satisfaction and loyalty of its customers?

Does the company describe the implementation of its community policy through a public commitment from a senior management or board member? AND Does the company describe the implementation of its community policy through the processes in place?

Does the company monitor or measure its performance on employment quality?

Operating income percentage change in the last three years.

Does the company have a golden parachute or other restrictive clauses related to changes of control?

Does the company monitor the use of inside information through the use of surveys or measurements?

Does the company monitor the customer satisfaction or its reputation and relations with communities through the use of surveys or measurements?

Does the company describe, claim to have or mention the processes it uses to accomplish environmental product innovation?

Does the company monitor the employee satisfaction through the use of surveys or measurements? (23)

Does the company set specific objectives to be achieved on customer satisfaction or fair competition?

Does the company monitor the board functions through the establishment of a corporate governance committee?

Does the company have an external auditor of its CSR/H\&S/Sustainability report?

Does the company monitor the shareholder rights through the establishment of a corporate governance committee?

Does the company claim to apply quality management systems, such as ISO 9000, Six Sigma, Lean Manufacturing, Lean Sigma,

TQM or any other similar quality principles?

Does the company explain how it engages with its stakeholders?

Is the company's CSR report published in accordance with the GRI guidelines? 
Submit or recommend next manuscript to SCIRP and we will provide best service for you:

Accepting pre-submission inquiries through Email, Facebook, LinkedIn, Twitter, etc. A wide selection of journals (inclusive of 9 subjects, more than 200 journals)

Providing 24-hour high-quality service

User-friendly online submission system

Fair and swift peer-review system

Efficient typesetting and proofreading procedure

Display of the result of downloads and visits, as well as the number of cited articles

Maximum dissemination of your research work

Submit your manuscript at: http://papersubmission.scirp.org/

Or contact tel@scirp.org 